\title{
Healthcare professionals' perception of mental health in primary care
}

\author{
Percepção dos profissionais de saúde sobre saúde mental na atenção básica \\ Percepción de los profesionales de salud sobre salud mental en la Atención Básica
}

Georgia Dalla Valle Garcia'
ORCID: 0000-0002-4077-9026

Daniela Viganó Zanoti-Jeronymo"

ORCID: 0000-0002-6131-3890

Gustavo Zambenedetti"I

ORCID: 0000-0002-7372-9930

Michele da Rocha Cervo"'I

ORCID: 0000-0003-3523-9292

Marília Daniella Machado Araújo Cavalcante" ORCID: 0000-0002-7685-6679

'Universidade de São Paulo. São Paulo, São Paulo, Brazil.

"Universidade Estadual do Centro-Oeste. Guarapuava,

Paraná, Brazil.

I' Universidade Estadual do Centro-Oeste. Irati, Paraná, Brazil.

How to cite this article:

Garcia GDV, Zanoti-Jeronymo DV, Zambenedetti G, Cervo MR, Cavalcante MDMA. Healthcare professionals' perception of mental health in primary care. Rev Bras Enferm. 2020;73(1):e20180201. doi: http://dx.doi.org/10.1590/0034-7167-2018-02011

Corresponding Author: Daniela Viganó Zanoti-Jeronymo E-mail: danielazanoti@uol.com.br

EDITOR IN CHIEF: Antonio José de Almeida Filho

Submission: 04-23-2018

Approval: 06-12-2018

\section{ABSTRACT}

Objective: To characterize the mental health care provided in Primary Care from the perception of health professionals in the cities to the 5th Regional Health Center of the state of Paraná. Method: An exploratory qualitative research. Participants were 121 health professionals working in primary care in the 20 cities of 5 th Regional Health Center of the state of Parana. Twenty-two focus groups were recorded, transcribed and analyzed by content analysis. Results: Five thematic categories emerged, of which two were analyzed in this study: actions that professionals consider to be mental health actions; mental health actions developed by Primary Care professionals. Final Considerations: Despite of the indications of inclusion of mental health actions in Primary Care, this relationship is still occasional and unplanned. Policies that foster this interaction from a psychosocial perspective are needed.

Descriptors: Primary Health Care; Mental Health Services; Health Personnel; Mental Health; Delivery of Health Care.

\section{RESUMO}

Objetivo: Caracterizar as ações em Saúde Mental desenvolvidas na Atenção Básica segundo a percepção dos profissionais de saúde dos municípios pertencentes à $5^{2}$ Regional de Saúde do estado do Paraná. Método: Estudo exploratório, com abordagem qualitativa. Participaram 121 profissionais de saúde atuantes na atenção básica dos 20 municípios

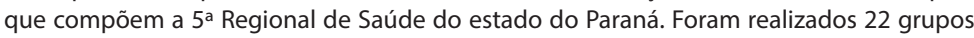
focais, os quais foram gravados e transcritos, para posterior tratamento através da análise de conteúdo. Resultados: Foram elencadas cinco categorias temáticas, das quais duas são analisadas neste artigo: ações que os profissionais consideram ser de saúde mental e ações de saúde mental desenvolvidas pelos profissionais da Atenção Básica. Considerações Finais: Apesar dos indicativos da inclusão das ações de saúde mental na Atenção Básica, essa relação ainda é pontual e pouco planejada, sendo necessárias políticas que fomentem tal interface, na perspectiva psicossocial.

Descritores: Atenção Primária à Saúde; Serviços de Saúde Mental; Pessoal de Saúde; Saúde Mental; Assistência à Saúde.

\section{RESUMEN}

Objetivo: caracterizar las acciones en salud mental desarrolladas en la Atención Básica según la percepción de los profesionales de salud de los municipios pertenecientes a la 5 a Regional de Salud del estado de Paraná. Método: estudio exploratorio cualitativo. Participación de 121 profesionales de salud que trabajan en la atención básica de los 20 municipios que componen la 5a Regional de Salud del estado de Paraná. Se realizaron 22 grupos focales, los cuales fueron grabados y transcritos, para posterior análisis de contenido. Resultados: se enumeraron cinco categorías temáticas, de las cuales dos son analizadas en este artículo: acciones que los profesionales consideran ser de salud mental; acciones de salud mental desarrolladas por los profesionales de atención básica. Consideraciones finales: a pesar de encontrar evidencias de la inserción de la salud mental en la atención básica, esta relación todavía es puntual y poco planificada. Son necesarias políticas que fomenten esta interfaz, desde la perspectiva psicosocial

Descriptores: Atención Primaria de Salud; Servicios de Salud Mental; Personal de Salud; Salud Mental; Prestación de Atención de Salud. 


\section{INTRODUCTION}

Several mental health $(\mathrm{MH})$ demands are identified everyday by Community Health Workers (CHW) and Family Health Strategy (FHS) teams. These are situations that require immediate interventions that can avoid unnecessary use of more complex care resources. These problems are associated with harmful use of alcohol and other drugs, patients coming from psychiatric hospitals, inadequate use of medications, severe mental disorders and situations resulting from violence and social exclusion ${ }^{(1)}$.

The identification and follow-up of these situations, which are part of the activities developed by Primary Health Care (PHC) teams, are fundamental steps for overcoming the medical-psychiatric and hospital model of $\mathrm{MH}$ care. It is worth remembering that everybody can show signs of psychic suffering at some stage of life ${ }^{(1)}$.

There are many possibilities for $\mathrm{MH}$ care in $\mathrm{PHC}$; however, practices such as user Embracement and qualified listening are little explored by the FHS teams, maintaining the logic of medicalization and health care ${ }^{(1)}$.

FHS units allow geographic knowledge of the population and enable health professionals to develop a close relationship with the clients, making $\mathrm{MH}$ care more strategic. These characteristics allow health professionals to frequently encounter individuals suffering from psychological distress; however, this same peculiarity causes doubts, fears and difficulties in these teams ${ }^{(2)}$.

In PHC, care is offered in known territory, in a close relationship with the people of the community (decentralization), in the sense of knowing them and their life histories, their links with the community and their needs. For these reasons, $\mathrm{PHC}$ is a strategic level for $\mathrm{MH}$ care and is crucial in the discussion about health care networks, since it is a reference for the population, and it is responsible for organizing caregiving ${ }^{(2)}$.

The Psychiatric Reform (PR) is a movement that began in Brazil in the last years of the 70's with the Movement of Mental Health Workers (MTSM). It criticizes the psychiatric model and advocates a change from a hospital care model for patients with mental illness or mental distress to a care model that allows them to reenter the community after care and shelter provided by an integrated network for $\mathrm{MH}$ care ${ }^{(3)}$.

In the 1990s, federal laws that were passed reflected the progress of political and social mobilization. Law $10.216^{(4)}$, enacted by the National Congress in 2001, affirms the rights of people with mental disorders and redirects the $\mathrm{MH}$ care model. The Psychosocial Care Networks (RAPS) were greatly expanded and became indispensable for MH care, through Presidential Decree no. 7,508/2011.

According to Costa-Rosa ${ }^{(5)}$, the institutional units part of the psychosocial care model for $\mathrm{MH}$ are the Psychosocial Care Centers (CAPS), the Psychosocial Care Units, Day Hospitals, Mental Health Clinics, multi-professional Mental Health teams in the Health Centers, Mental Health Sectors in general hospitals, Therapeutic Workshops, Therapeutic Residences and PHC itself.

As for the network that replaces the psychiatric hospital, the State of Paraná has 118 CAPS, which is equivalent to 0.89 CAPS per 100,000 inhabitants. This is a very good number, considering that the Ministry of Health recommends one CAPS per 100,000 inhabitants. There are 10 Therapeutic Residence Services and 158 beneficiaries of the Going Back Home Program in Paraná(6).
The State of Paraná is one of the great centers of hospital tradition, with a high concentration of psychiatric care beds. It is currently the 3rd state of Brazil in number of psychiatric hospitals, with 15 hospitals and a total of 2,273 beds. There are only 10 psychiatric beds distributed in 2 general hospitals ${ }^{(6)}$.

Because it is a relatively recent model, the $\mathrm{MH}$ care network, especially of smaller cities, requires some attention. According to a study by Luzio and L'Abbate ${ }^{(7)}$ about $\mathrm{MH}$ in small and mediumsized cities, most of these cities know little about $\mathrm{MH}$ national policy. Therefore, it is important to know and understand the health care instruments of the city, and based on data collected, it is possible to analyze what is actually being done and what is still a challenge in $\mathrm{MH}$ practices.

\section{OBJECTIVE}

To characterize the mental health care provided in Primary Care in the perception of health professionals.

\section{METHOD}

\section{Ethical aspects}

The study was approved by the Research Ethics Committee from the Midwestern State University in Parana. Participants signed the Informed Consent Term, in accordance with Resolution $466 / 2012$ of the National Health Council(8).

\section{Type of study}

This is an exploratory qualitative research.

The present study is part of the Research Project entitled "Network Components in Mental Health Care: reality of the 4th and 5th Regional Health Centers", subsidized by the Research Program for the Unified Health System: Shared Health Management PPSUS - 2011 Edition and conducted between 2013 and 2017.

\section{Study setting}

The research was carried out in the 20 cities of the 5 th Regional Health Center of the State of Paraná. The organization of health care systems in the state of Paraná complies with the principle of decentralization of the United Health System (SUS), dividing the state into 4 health macro regions and 22 regional health centers. These regional bodies are an intermediary administrative body to the State Health Department. This organization facilitates cooperation between the cities to meet the health needs of this area and provides support in a nearby administrative body, avoiding commuting to the state capital ${ }^{(9)}$.

\section{Data source}

The participants of the research were the professionals who work in PHC in the 20 cities of the 5th Regional Health Center of Paraná. The participants were 121 professionals, appointed by $\mathrm{MH}$ managers and coordinators and invited by the research team to participate in the focus groups. 
Most of the participants were female (86.8\%); $46.7 \%$ of participants were between 31 and 40 years old; $38.9 \%$ were nurses; and $41.5 \%$ had been working in PHC from 1 to 5 years. Table 1 presents the characterization of the participants.

Table 1 - Characterization of the Professionals of the Primary Care Focal Groups, 5th Regional Health, Paraná, Brazil

\begin{tabular}{|c|c|c|c|}
\hline \multicolumn{2}{|l|}{ Characteristics } & \multirow{2}{*}{$\begin{array}{c}\mathbf{n} \\
16\end{array}$} & \multirow{2}{*}{$\begin{array}{c}\% \\
13.2\end{array}$} \\
\hline Gender & Male & & \\
\hline & Female & 105 & 86.8 \\
\hline \multirow[t]{5}{*}{ Age } & 21- 30 Years & 24 & 22.4 \\
\hline & 31- 40 Years & 50 & 46.7 \\
\hline & 41- 50 Years & 20 & 18.7 \\
\hline & $51-60$ Years & 11 & 10.3 \\
\hline & $>61$ Years & 2 & 1.9 \\
\hline \multirow[t]{8}{*}{ Profession } & Nurse & 44 & 38.9 \\
\hline & Psychologist & 2 & 1.8 \\
\hline & Physician & 3 & 2.65 \\
\hline & Nursing Technician & 13 & 11.5 \\
\hline & Nursing Assistant & 10 & 8.85 \\
\hline & $\mathrm{CHA}$ & 33 & 29.2 \\
\hline & Pharmacist & 1 & 0.9 \\
\hline & Others & 7 & 6.2 \\
\hline \multirow[t]{4}{*}{ Years after graduation } & 3- 6 Years & 23 & 31.9 \\
\hline & 7- 16 Years & 39 & 54.2 \\
\hline & 17- 26 Years & 9 & 12.5 \\
\hline & 27- 37 Years & 1 & 1.4 \\
\hline \multirow[t]{6}{*}{ Has a graduate degree } & YES & 43 & 59.7 \\
\hline & Public Health & 11 & 25.6 \\
\hline & Mental Health & 1 & 2.3 \\
\hline & Family Health & 4 & 9.3 \\
\hline & Others & 27 & 62.8 \\
\hline & NO & 29 & 40.3 \\
\hline \multirow{6}{*}{$\begin{array}{l}\text { Time working in Primary } \\
\text { Health Care }\end{array}$} & 1- 5 Years & 44 & 41.5 \\
\hline & 6- 10 Years & 22 & 20.8 \\
\hline & 11- 15 Years & 17 & 16.1 \\
\hline & 16- 20 Years & 12 & 11.3 \\
\hline & 21- 25 Years & 8 & 7.5 \\
\hline & 30- 42 Years & 3 & 2.8 \\
\hline
\end{tabular}

\section{Data collection and organization}

Data from the transcriptions of the focus groups with PHC professionals from the 5th Regional Health Center of the State of Paraná were used. These transcriptions are available in the database of the research "Network Components in Mental Health Care: reality of the 4th and 5th Regional Health Centers".

The focus groups were held in the 20 cities of the 5 th Regional Health Center of the State of Paraná. One focus group was carried out in each city, except for Guarapuava, where three focus groups were carried out due to the large number of primary care units.

The $\mathrm{MH}$ coordinators of the cities were contacted and indicated a date for the focus group. At least one member of each $\mathrm{PHC}$ team in the city was asked to participate.

The focus groups were recorded, and the speeches of the professionals were later transcribed.

\section{Data analysis}

The data was analyzed by content analysis, which is the set of communication analysis techniques aimed at obtaining, by systematic procedures and description of the content of the messages, indicators (quantitative or not) that allow inference of knowledge about the conditions of production/reception of these messages ${ }^{(10)}$.

In the first phase, the transcriptions of the PHC focus groups were read, defining the corpus for formulating and reformulating the hypotheses and objectives of the work. Then, the data referring to the questions of the focus group script that would reach the objective of the study were selected. Finally, the data from the speeches selected from the transcription of the PHC focus groups were categorized, and five categories emerged: 1) Mental health care demands; 2) Actions in primary care considered by professionals as mental health care; 3 ) Mental health actions developed in primary care; 4) Difficulties to carry out actions; 5) Possibilities for the development of actions.

In this study, the second and third categories were selected for analysis, aiming to deepen their understanding.

\section{RESULTS}

\section{Perception of professionals regarding mental health ac- tions in Primary Health Care}

This category shows which actions are considered by PHC professionals as mental health actions, which can be for health promotion, disease prevention, treatment or rehabilitation. The speeches express expectations of activities to be carried out.

The actions the professionals thought that should be developed for $\mathrm{MH}$ are groups, $\mathrm{MH}$ education for the population, physical activity and actions to prevent mental disorders, such as conducting lectures on alcohol and drugs in schools.

\section{[...] education about Mental Health problems for the population, so that they have knowledge [...]. (GFAB1) \\ Iconsider preventive work, groups, lectures as health actions. (GFAB8) \\ [...] walks are actually healthy [...] some people do gymnastics every Monday afternoon with the physiotherapist. (GFAB14)}

The actions of raising awareness and the family approach are also highlighted. Professionals believe that greater involvement of the family and better knowledge about $\mathrm{MH}$ are associated with a better treatment development.

[...] / think we must raise awareness among the families to accept the patient, they just want to admit the patient, we have to talk to the family members so they can help with the patient. (GFAB1)

[...] the approach to the family member and to the patients, so that we can have better understanding of the case and then refer the patient if necessary [...]. (GFAB17)

The First Consultation was also pointed out as a $\mathrm{MH}$ action. The professionals highlighted the actions: reception, risk classification/stratification and demand assessment. 
Healthcare professionals' perception of mental health in primary care Garcia GDV, Zanoti-Jeronymo DV, Zambenedetti G, Cervo MR، Cavalcante MDMA.

[...] the first consultation and the reception, because if the person does not have a physical problem but is frequently looking for our care, and we do not find a physical problem, it's because the person needs to share, or do something, or talk [...]. (GFAB10)

\section{[...] risk classification [...]. (GFAB15)}

A result that still needs to be addressed and discussed by the teams is the role of each professional in their area of knowledge, and not only the role of the doctor and psychologist in their consultations. We can reflect about how the medical knowledge is still considered superior to other knowledge and how the consultation and drug therapy are still prioritized.

[...] support from the medical area, with their correct evaluation, so we can get this diagnosis and assemble these groups [...]. (GFAB5)

I consider an action when they appear at one of our consultations, the doctor makes a prescription and if the situation gets worse, the doctors refers the patient [...]. (GFAB6)

Basically, having more psychologists so we can refer these patients. (GFAB18)

Psychologists are mentioned because the science itself is directly related to $\mathrm{MH}$; however, professionals emphasize individual consultations and do not see the health prevention and promotion actions that can be developed by the psychologist through groups, interconsultations, and matrix support.

Home visits are fundamental tools in care and have been pointed out as actions for $\mathrm{MH}$. They promote dialogue and exchange of experiences between those involved in the assistance.

And there are also home visits, us and the NASF [Family Health Support Centers]. (GFAB11)

[...] so that we can have better understanding of the case and then refer the patient if necessary [...] it is a multidisciplinary work. (GFAB17)

It is worth noting the contradiction regarding the importance of each member of the team: when referring to the home visit, the professionals highlighted the importance of the multi-professional team; however, separately, they referred only to the doctor and the psychologist as $\mathrm{MH}$ care professionals.

Finally, referrals within the network were mentioned as actions for $\mathrm{MH}$.

In my FHS everything is based on referring to CAPS, the clinical doctor of the unit gives us the referral and we refer the patient... (GFBA7A)

[...] we talk, if it is a case for referral, we see what the patient needs from here and then we refer [...]. (GFAB20)

Using the other parts of the network is fundamental for a comprehensive assistance; however, this cannot be seen as the main action, since it takes the responsibility of the team and puts it on the other service, only forwarding the clients.

\section{Mental health actions developed in Primary Care}

This category shows the actions developed by professionals in PHC in their daily work. Different from the previous category, which analyzed expectations of actions, in this category, we analyzed what the participants report doing in the field of mental health. The analysis of this category along with the previous one shows interesting results, since, despite their recognition of $\mathrm{MH}$ demands and actions, professionals do not always develop the actions they expected during their daily practice.

In agreement with what was previously pointed out, the $\mathrm{MH}$ actions that emerged were: pre-consultation/listening/risk classification; education; actions to promote $\mathrm{MH}$ and prevent mental disorders; assistance from specialized professionals; home visit; and referrals within the network. One activity that is developed but had not been previously cited was monitoring the patient and the medication. There were also focus groups where the participants reported they did not develop $\mathrm{MH}$ actions.

Actions to Promote Mental Health and Prevent Mental Disorders.

[...] the only actions that we do is when we go to schools and talk about alcohol and drugs, which would be the standard preventive action regarding alcohol and other drugs; but when it comes to schizophrenia, bipolar disorder, these other things, we have nothing. (GFAB4)

All the groups we have for pregnant women, diabetes, where they get together and exchange ideas, there's another one for physical activity, those help a lot in Mental Health. (GFAB9)

Home visits.

[...] we make the home visit, provide assistance, and, if necessary, we pass the case to the girls and the girls come and see if they need to refer the patient to the doctor or to the hospital [...]. (GFA5)

When we realize that some patient needs care, we talk or even visit [...]. (GFAB11)

Referrals within the Network.

[...] if we see some complication, we'll call CRAS for them to make a visit. (GFAB6)

[...] pre-consultation and clinical consultation, and then, if necessary, CAPS. (GFAB7B)

[...] we see the need to refer to the NASF, to the psychologist [...] And also when it is necessary to refer to social assistance, when the case involves the social context of the patient. (GFAB11)

Counseling.

Counseling is prevention, we've learned a lot about how to deal with families in this course that we had, so I myself try to provide guidance whenever I can talk to the family, the people who are always close to that person [...] We've even learned in the course that the family and the people that are caring for the patient are sicker than the patient himself. (GFAB8) 
And also in our individual actions, in our visits, sometimes we see a family and we realize someone is not fine, is on the verge of depression, then we can recommend a consultation, participation is some group, you know? Sometimes, when people have a problem, they isolate themselves, and this can lead to a Mental Health problem like depression [...]. (GFAB14)

Pre-consultation/Listening/Risk classification.

[...] pre-consultation and clinical consultation, and then, if necessary, CAPS. (GFAB7B)

[...] we welcome and listen to people, because most people do not come here, in the unit, just for the medication, they want to talk, to feel welcomed, to feel loved, to vent. (GFAB10)

Patient/medication follow-up.

[...] seeing if the medication the patient is taking is having the expected effect; this is evaluated by the team as a whole, the CHAs in their home visits, the team in the unit [...] I follow-up patients and I see the blister pack, I count the pills taken [...] the CHAs follow-up patients in their areas. (GFAB3)

[...] the only action that we do is very restricted to each professional and in each area, we always see the patient's chart, to check if he was hospitalized, if he comes to get the medication every month. It is the action of each professional. It is very little, almost nothing is done [...]. (GFAB6)

We pay attention to see if they are taking the medication correctly. (GFAB19)

Assistance from specialized professionals.

[...] if it is necessary to refer to the doctor or to the hospital [...]. (GFA5)

[...] he sees if it is necessary to refer to the NASF, to the psychologist. (GFAB11)

[...] advises to come to the psychologist or to talk to the PSF nurse, who can refer to the psychologist. (GFAB12)

Do not develop actions.

We do not have preventive actions, we take care only when the patient is already with the chronic disease, and this is because no one wants to get involved [...]. (GFAB4)

There is not. There's no time here, it's too hectic. (GFAB13)

[...] because we have a small number of employees in the BHUs, there are actions that we can not develop [...]. (GFAB16)

\section{DISCUSSION}

The highlighted results regarding health promotion and disease prevention are in line with the recommendations of the Ministry of Health presented in Caderno 34 of $\mathrm{PHC}^{(2)}$, which all professionals can access, as well as the general population.

The interaction between PHC and the schools in their territory enables actions to promote $\mathrm{MH}$ and prevent problems in the area. The health unit sometimes does not recognize the school as an expanded health center, limiting action to referrals to specialists. Schools must be seen as a space for the development of promotion and prevention actions, and even a place for intervention in serious situations ${ }^{(2)}$.

However, one must be careful when interacting with schools, avoiding actions with a passive learning method and one-off interventions in the form of lectures ${ }^{(11)}$, since the objective should be to develop user autonomy.

Groups can be used as psychosocial interventions in PHC. They are strategies with important impact for providing subjectivecollective perspectives, comprehensive care, development of autonomy and production of health care ${ }^{(2)}$.

There are conflicting views regarding the Network: sometimes it is seen as a problem (because it is incomplete, bureaucratic, fragmented, etc.), and sometimes it is seen as the solution and the necessary answer. Schneider ${ }^{(12)}$ expatiates on the complex and strong relationships found in the Networks and highlights the importance of keeping track of the interactions between the different sectors, so that the fragilities of the Networks can be overcome. Quinderé, Jorge and Franco ${ }^{(13)}$ understand that networks can have several forms of organization, they can be pyramidal, circular or even rhizomatic.

The way specialized services and professionals are perceived is also debatable, as they are seen more as possibilities of referral than as spaces to articulate and work together with. Therefore, the specialized service is at risk of being seen as a possibility to transfer responsibility, instead of a space to share responsibility with, which is similar to what has been observed in other studies ${ }^{(14)}$.

Matrix support is a new way of producing health in which two or more teams, in a process of shared construction, establish a proposal of a pedagogical-therapeutic intervention for the cases $^{(15)}$. This new model can help the transformation of the work processes, in the direction of sharing care between the teams ${ }^{(16)}$. Matrix support can also provide greater safety in the work of primary care professionals, since they do not always feel secure when dealing with cases that involve mental health ${ }^{(17)}$.

Moreover, the results show a care model centered on medication and symptoms and demonstrate that PHC can take on mental health demands, but with the same logic as the care model. The PR proposal is more comprehensive; it involves the diversity of therapeutic resources and considers patients with psychological suffering as complex subjects, who are not limited to a disease or a set of symptoms.

It is understood that the demands are previously determined and influenced by what is offered in terms of $\mathrm{MH}$, that is, medicalpsychiatric diagnoses and treatment variables such as searching for specialists, requests and referrals for hospitalization and, mainly, use of medications ${ }^{(18)}$.

The use of medication as a marker of treatment success is something that has been questioned, since side effects of treatment must also be considered, as well as the autonomy of the patient to negotiate their medication ${ }^{(19)}$, aiming at achieving quality of life and autonomy ${ }^{(20)}$

According to Quinderé, Jorge and Franco ${ }^{(13)}$

"Non-adherence" to medication can be the patient's way out of certain side effects known to be harmful - for example, for their affective life. This act should be analyzed from the perspective of the client and workers should be willing to 
negotiate the therapeutic treatment, without immediately seeing non-adherence as a negative fact.

Augsburger and Gerlero ${ }^{(21)}$ argue that it is necessary to analyze the effects of expanding access to psychopharmaceuticals in primary care, since it would involve a contradiction: while access to medicines is a part of the right to health, this could also promote or extend the process of medicalization of life.

The medical model is also based on hegemonic medical assistance, with care focused on the act of prescribing as a producer of procedures and health care.

Regarding the groups that did not mention actions for $\mathrm{MH}$, it is worth noting that there are actions that these professionals can include in their routine or that are even already part of their work, but are not seen as $\mathrm{MH}$ actions, such as reception, referrals within the network, groups, among others. Authors such as Paim et al. ${ }^{(22)}$ have shown that, despite the important expansion of Primary Care and access to health in Brazil, changing the model is still a challenge.

According to the National Policy of Primary Care, the competences of PHC are: reception; risk stratification; organization of care; articulation of the intra- and inter-sectoral networks; registration of users; creation of bonds; responsibility for the assigned users; provision of care and decisive assistance for low- and medium-risk users; sharing care of high-risk users with the CAPS; conducting health education activities; and developing collective activities ${ }^{(23)}$.

The difficulties identified showed that, even though some difficulties are not associated with the professionals, light technology instruments are not recognized as important strategies when monitoring the user. Health promotion actions that require offering culture and leisure for the population are also not appreciated by the teams. The healthcare sector is isolated from others such as Education, Culture and Leisure, Justice, Sport, among others.

As potentialities, we can point to the expansion of the FHS teams and their presence in the territories where the population lives, with the teams and Community Health Workers. The training needs to include continuing education, so that professionals are always up to date with new modes of care and sensitized to mental health care. The availability of medications and consultations in primary care is also considered a potentiality, provided that those are not the only and main resources but coexist with a variety of therapeutic options - which were not reported in this research.

\section{Limitations of the study}

It was not possible to map or systematize experiences of inclusion of $\mathrm{MH}$ actions in $\mathrm{PHC}$ that were considered successful or as good practices. The participants showed little familiarity with the issue and only developed occasional actions, which indicates the need for professional qualification in psychosocial care for mental health.

\section{Contributions to the area of nursing, health or public policy}

It should be noted that the research participants were mainly nursing professionals (nurses, technicians and assistants), who were part of $\mathrm{PHC}$ teams and were considered experienced in $\mathrm{MH}$. The inclusion of $\mathrm{MH}$ in $\mathrm{PHC}$ requires planning and can't be detached from nurses' work. Thus, the present study indicates the need to deepen the discussion about the professional and continuous training of nurses, in order to produce contributions to the field of collective health and $\mathrm{MH}$.

\section{FINAL CONSIDERATIONS}

The characterization of $\mathrm{MH}$ care provided in $\mathrm{PHC}$, according to the perception of health professionals in the cities of the 5th Regional Health Center of the state of Paraná, demonstrated the need to strengthen knowledge on the Mental Health Care Network. The existing actions partially comply with the recommendations of MH Public Policies, but the network still has a long way to go. The cities present difficulties related to the articulation of networks and management of work processes and still need to overcome stigmas related to $\mathrm{MH}$.

It is also necessary to overcome the medical model of care and expand care to all the professionals of the team, since all of them are fundamental for creating bonds, monitoring the user and the family, and developing activities at the territorial level. In this sense, it is not enough to have mental health actions in Primary Care; these actions must also be in accordance with the principles of psychosocial care, aiming for greater effectiveness, guarantee of rights, comprehensiveness and compliance with national public policies.

\section{FUNDING}

The present study is part of the Research Project entitled "Network Components in Mental Health Care: reality of the 4th and 5th Regional Health Centers", which was financed by the Research Program for the Unified Health System: Shared Health Management PPSUS - Edition 2011, funded by the Araucária Foundation (Protocol: 30,037, Agreement: 1289/201), and conducted between 2013 and 2017.

\section{REFERENCES}

1. Paraná (Estado). Secretaria de Estado da Saúde (SESA). Saúde Mental [Internet]. Curitiba: SESA; 2017 [cited 2017 Nov 20]. Available from: http://www.saude.pr.gov.br/modules/conteudo/conteudo.php?conteudo=2862

2. Ministério da Saúde (BR). Secretaria de Atenção à Saúde. Departamento de Atenção Básica. Saúde Mental [Internet]. Brasília: Ministério da Saúde; 2013 [cited 2017 Nov 20]. (Cadernos de Atenção Básica, 34). Available from: http://bvsms.saude.gov.br/bvs/publicacoes/cadernos_ atencao_basica_34_saude_mental.pdf

3. Amarante P. Saúde Mental e Atenção Psicossocial. Rio de Janeiro: Fiocruz; 2007. 
4. Ministério da Saúde (BR). Lei no 10.216 de 6 de abril de 2001. Dispõe sobre a proteção e os direitos das pessoas portadoras de transtornos mentais e redireciona o modelo assistencial em saúde mental [Internet]. Brasília; 2001 [cited 2017 Nov 20]. Available from: http://www. planalto.gov.br/ccivil_03/leis/leis_2001//10216.htm

5. Costa-Rosa A. O modo psicossocial: um paradigma das práticas substitutivas ao modo asilar. In: Amarante P, organizador. Ensaios: subjetividade, saúde mental, sociedade. Rio de Janeiro: Editora Fiocruz; 2000. p. 141-68

6. Ministério da Saúde (BR). Saúde Mental em Dados - 12, ano 10, n. 12. Informativo eletrônico [Internet]. Brasília: Ministério da Saúde; 2015 [cited 2017 Nov 20]. Available from: http://www.mhinnovation.net/sites/default/files/downloads/innovation/reports/Report_12-edicao-doSaude-Mental-em-Dados.pdf

7. Luzio CA, L'Abbate S. A atenção em Saúde Mental em municípios de pequeno e médio portes: ressonâncias da reforma psiquiátrica. Ciênc Saúde Colet. 2009;14(1):105-16. doi: 10.1590/S1413-81232009000100016

8. Ministério da Saúde (BR). Conselho Nacional de Saúde (CNS). Resolução n. 466, de 12 de dezembro de 2012. Dispõe sobre as diretrizes e normas regulamentadoras de pesquisa envolvendo seres humanos. Brasília: Ministério da Saúde; 2013 [cited 2017 Nov 20]. Available from: http://bvsms.saude.gov.br/bvs/saudelegis/cns/2013/res0466_12_12_2012.html

9. Paraná (Estado). Secretaria de Estado de Saúde do Paraná. Mapa Político do Estado do Paraná [Internet]. Curitiba: SESA; 2017 [cited 2017 Nov 20]. Available from: http://www.saude.pr.gov.br/arquivos/File/mapa_das_macrorregionais_colorido_.jpg

10. Bardin L. Análise de Conteúdo. São Paulo: Edições 70; 2011.

11. Ministério da Saúde (BR). Adolescentes e jovens para a educação entre pares: saúde e prevenção nas escolas álcool e outras drogas [Internet]. Brasília: Ministério da Saúde; 2011 [cited 2017 Nov 20]. Available from: http://unesdoc.unesco.org/ images/0022/002218/221899por.pdf

12. Schneider ARS. A rede de atenção em saúde mental: a importância da interação entre a atenção primária e os serviços de saúde mental. Ciênc Saúde. 2009;2(2):78-84. doi: 10.15448/1983-652X.2009.2.4843

13. Quinderé PHD, Jorge MSB, Franco TB. Rede de Atenção Psicossocial: qual o lugar da saúde mental? Physis. 2014;24(1):253-71. doi: 10.1590/ S0103-73312014000100014

14. Zambenedetti G, Perrone CM. O processo de construção de uma rede de atenção em Saúde Mental: desafios e potencialidades no processo de Reforma Psiquiátrica. Physis. 2008;18(2):277-93. doi: 10.1590/S0103-73312008000200005

15. Jorge MSB, Sousa FSP, Franco TB. Apoio matricial: dispositivo para resolução de casos clínicos de saúde mental na Atenção Primária à Saúde. Rev Bras Enferm. 2013;66(5):738-44. doi: 10.1590/S0034-71672013000500015

16. Dantas NF, Passos ICF. Apoio matricial em saúde mental no SUS de Belo Horizonte: perspectiva dos trabalhadores. Trab Educ Saúde. 2018;16(1):201-20. doi: 10.1590/1981-7746-sol00097

17. Prata NIS, Groisman D, Martins DA, Rabello ET, Mora FS, Jorge MA, et al. Saúde mental e atenção básica: território, violência e o desafio das abordagens psicossociais. Trab Educ Saúde. 2017;15(1):33-53. doi: 10.1590/1981-7746-sol00046

18. Schutel TAA, Rodrigues J, Peres GM. A concepção de demanda em saúde mental na Atenção Primária à Saúde. Ciênc Saúde. 2015;8(2):85-93. doi: 10.15448/1983-652X.2015.2.20167

19. Passos E, Palombini AL, Campos RO, Rodrigues SE, Melo J, Maggi PM, et al. Autonomia e cogestão na prática em saúde mental: o dispositivo da gestão autônoma da medicação (GAM). Aletheia [Internet]. 2013 [cited 2018 Jan 13];41:24-38. Available from: http://pepsic.bvsalud.org/ scielo.php?script=sci_arttext\&pid=S1413-03942013000200003\&lng=pt

20. Zambillo M, Palombini AL. Autonomias errantes: processos de autonomização em saúde mental. Estud Psicol (Natal). 2017;22(1):78-88. doi: 10.22491/1678-4669.20170009

21. Augsburger AC, Gerlero SS. La accesibilidad al tratamiento psicofarmacológico en la estrategia de atención primaria de la salud: una mirada crítica sobre las paradojas del derecho a la salud [Internet]. Cad Bras Saúde Ment. 2017;9(24):96-122 [cited 2018 Jan 13]. Available from: http://incubadora.periodicos.ufsc.br/index.php/cbsm/article/view/5048

22. Paim J, Travassos C, Almeida C, Bahia L, Macinko J. The Brazilian health system: history, advances, and challenges. Lancet. 2011;377(9779):1778-97. doi: 10.1016/S0140-6736(11)60054-8

23. Paraná (Estado). Secretaria de Estado da Saúde (SESA). Coordenação Estadual de Saúde Mental. Rede de Atenção à Saúde Mental [Internet]. Curitiba; 2014 [cited 2017 Nov 20]. Available from: http://www.crianca.mppr.mp.br/arquivos/File/antidrogas/rede_de_atencao_a_saude_ mental_no_parana_2014.pdf 